\title{
Emergency department thoracotomy in a patient with non-traumatic pulseless electrical activity: potential widening of the therapeutic horizon of a high-specialty intervention
}

Toracotomía en el departamento de urgencias en una paciente con actividad eléctrica sin pulso no traumática: potencial ampliación del horizonte terapéutico de una intervención de alta especialidad

Luis M. García-Núñez ${ }^{*}$, Irving I. Morales-Pogoda1, Edgar F. Hernández-García1, Juan A. Rodríguez-Inurrigarro², Raúl García-Ramírez ${ }^{1}$ and Fernando F. Arcaute-Velázquez ${ }^{1}$

${ }^{1}$ Hospital Central Militar; ${ }^{2}$ Military School of Public Health Graduates, Universidad del Ejército y Fuerza Aérea. Secretaría de la Defensa Nacional, Mexico City, Mexico

\begin{abstract}
Instituted under objective recommendations, Emergency Department Thoracotomy (EDT) has been described as a life-saving surgical maneuver in trauma patients arriving "in extremis." Nevertheless, there are few reports related to the experience regarding the use of the procedure in non-traumatic cardiopulmonary arrest. We describe the case of an obstetric patient exsanguinated by operative massive bleeding, where EDT was instituted reaching an optimal result for the survival and neurologic function. Additionally, we evaluate the literature related to this issue, which to the best of our knowledge, is critical to expand protocols of approach in non-traumatic cardiac arrest rhythm in high-volume hospitals.
\end{abstract}

KEY WORDS: Non-traumatic pulseless electrical activity. Thoracotomy. Emergency department.

\section{Resumen}

Instituida bajo recomendaciones objetivas, la toracotomía en el departamento de urgencias (TDU) se ha descrito como una maniobra quirúrgica salvatoria de la vida en pacientes traumatizados in extremis. Sin embargo, hay pocos reportes acerca de la experiencia con su empleo en la actividad eléctrica sin pulso no traumática. Describimos el caso de una paciente obstétrica exanguinada por sangrado masivo transoperatorio, en la que se realizó una TDU con un resultado óptimo para la vida y la función neurológica. Adicionalmente, evaluamos la literatura correspondiente al tema, que en lo mejor de nuestro conocimiento es crítica para expandir los protocolos de abordaje del ritmo de paro cardiaco no traumático en los hospitales de alto volumen.

PALABRAS CLAVE: Actividad eléctrica sin pulso no traumática. Toracotomía. Departamento de urgencias.

\author{
Correspondence: \\ *Luis M. García-Núñez \\ Enrique Sada Moguerza 17, cons. 144, Torre B, planta baja \\ C.P. 53100 , Naucalpan de Juárez, \\ Edo. de México, México \\ E-mail: Imgarcian@ hotmail.com
}

Date of reception: 14-03-2018

Date of acceptance: $21-04-2018$

DOI: $10.24875 / C I R U E . M 18000053$
Cir Cir. 2018;86:325-328

Contents available at PubMed www.cirugiaycirujanos.com 


\section{Introduction}

Emergency department thoracotomy (EDT) is a heroic procedure, which represents the last hope of life for many patients who arrive critically injured and in extremis at trauma centers. Used under objective recommendations by a surgeon who is knowledgeable about the technique, it has been shown to be highly useful in this scenario ${ }^{1-3}$.

Unfortunately, since the popularization of closed chest compressions in the decade of 1960, direct cardiac massage with open chest fell into disuse, making for direct cardiac compressions to be rarely practiced outside surgical scenarios ${ }^{4-6}$. However, over the last 20 years, great experience has been gained with open cardiac massage resuscitation, mainly due to the analysis of the results obtained with the practice of EDT in trauma.

Therefore, surgical audacity, based on solid scientific knowledge on cardiovascular collapse anatomophysiopathology and response to the procedure, has encouraged the use of EDT in non-traumatic pulseless electrical activity $(P E A)^{4,6,7}$. We report the case of a patient with non-traumatic PEA (due to massive obstetric hemorrhage) who underwent EDT with a good result for life and neurological recovery, which presumably opens an encouraging landscape in the management of this type of cases.

\section{Clinical case description}

A previously healthy 27-year-old woman with a history of three cesarean sections and one vaginal delivery (all of them preterm) and an ongoing non-controlled pregnancy of 26 weeks of gestation, arrived at a gyneco-obstetric institution with a 9-hour history of transvaginal bleeding. Upon admission, she was in state of shock (blood pressure $70 / 50 \mathrm{mmHg}$, heart rate 123 beats/min; $\mathrm{SpO}_{2} 63 \%$ ), with impaired sensorium, diaphoretic and with marbled complexion. On gynecological examination, the vulva and vagina were found with heavy bleeding, and pelvic exam was therefore obviated, while fetal heart rate was 138 beats/min. Laboratory tests showed evidence of deep anemia, thrombocytopenia, metabolic acidosis and coagulopathy. Transabdominal ultrasound showed the presence of complete placenta previa. From the emergency area she was brought to the operating room to terminate pregnancy via cesarean section, due to the presence of bleeding complete placenta previa.
In the operating room, with the aforementioned intervention, a male infant of 800 grams was obtained and brought intubated to the neonatal intensive care unit. It was not possible to completely remove the placenta due to the presence of placental accretism, thus resulting in continuous trans-operative bleeding, which activated institutional massive transfusion protocols. The patient had a cardiac arrest, which prompted the need for cardiopulmonary resuscitation, which she responded to after 4 minutes. Due to her critical condition, a supracervical obstetric hysterectomy was performed, with the bladder being wounded and primarily repaired. The surgical wound was packed and the skin was temporarily closed, in order to transfer the patient by land to the national reference institution Hospital Central Militar, which is a nearby tertiary care hospital with full human and material resources. Estimated intraoperative blood loss was $6,300 \mathrm{ml}$ and trans-operative total volumetric replacement was calculated at $13,600 \mathrm{ml}(2000 \mathrm{ml}$ of crystalloids, 17 packed red blood cell units, 5 fresh frozen plasma units and 3 platelet pools).

Immediately upon arrival at the reference center she presented a new cardiac arrest event, with electrical activity electrocardiographically documented. Therefore, EDT was undertaken using a Spangaro incision (left anterolateral approach). The operating surgeon found the heart containing blood in all four chambers; he performed a longitudinal pericardiotomy and started open cardiac massage, with ventricular fibrillation being obtained in response. Simultaneously, non-circumferential dissection was performed and clamping of the descending thoracic aorta was carried out with DeBakey-Crafoord clamps, in order to redistribute the effective circulating volume towards the coronary-cerebral circulation and limit sub-diaphragmatic blood loss. With no delay, the pharmacological and electrotherapy protocols for core rhythms treatment were also applied, thus transforming this fibrillation into sinus bradycardia (40 beats/min). One direct intraventricular dose of atropine $(1 \mathrm{mg})$ and adrenaline $(1 \mathrm{mg})$ was applied, with sinus rhythm (72 beats/min) being reached. After this, she was brought to the operating room for abdominal repackaging, temporary closure of the thoracotomy with placement of a left pleural tube and management with open abdomen. Aortic clamping total time was less than 15 minutes.

During the first 10 hours of her stay at the intensive care unit, the patient had two ventricular tachycardia events with hemodynamic repercussion, 
which were successfully managed with advanced cardiovascular support protocols. Intensive activities for the management of multifactorial coagulopathy and transfusion therapy were established. She evolved towards improvement and, 36 hours after the EDT, she was brought to the operating room for final closure of cavities. Mechanical ventilation weaning was possible 20 hours after her readmission to the unit. She was discharged from the critical care unit on the sixth day after admission and the pleural tube was removed shortly before her transfer to the regular hospital ward. The patient was discharged from the hospital on day 12 after her arrival, in good physical condition and with ability for self-care.

\section{Discussion}

We know that early defibrillation and high-quality cardiac compressions are possibly the most important aspects that lead to spontaneous circulation return in non-traumatic PEA ${ }^{1,4,6}$. However, in the presence of a traumatic cardiac arrest rhythm, when blood loss plays an essential role in the pathophysiology of collapse, efficient bleeding control becomes a critical therapeutic aspect, which should not overlooked by the operating surgeon ${ }^{7,8}$.

Under these principles of advanced cardiovascular support, it is possible that certain aspects concerning the practice of EDT in trauma are applicable to patients with non-traumatic PEA. García-Núñez et al. ${ }^{9}$, in a critical analysis of the literature related to perimortem cesarean section, indicate that, under optimal conditions, external chest compressions generate only one third of the calculated cardiac output, while the practice of open cardiac massage promotes an ejection fraction of $60-80 \%$, with a subsequent increase in cardiac output. On the other hand, Kornhall and Dol$v^{2}{ }^{4}$, in a similar study relative to EDT in non-traumatic PEA, noted that open chest cardiac compressions result in a mean cardiac index of $13.1 \mathrm{~L} / \mathrm{min} / \mathrm{m}^{2}$, compared to $0.61 \mathrm{~L} / \mathrm{min} / \mathrm{m}^{2}$ when closed-chest cardiac massage is practiced. In addition, mean coronary perfusion pressures obtained with both resuscitation methods are $32.6 \pm 17.8$ and $7.3 \pm 5.7 \mathrm{mmHg}$, respectively.

Furthermore, for the same reason that it is important for aortic clamping to be highlighted as an unquestionable objective of EDT in trauma, given that it is an invaluable maneuver to inhibit sub-diaphragmatic bleeding, it is essential pointing at the fact that, in patients with non-traumatic PEA, this strategy shows one of its beneficial effects that is more favorable for survival and neurological recovery: effective residual circulating volume redistribution towards the coronary and cerebral circulation. This way, although the survival rate of traumatized patients undergoing EDT has been historically estimated to be, at best, $38 \%$, since the inclusion of protocol-guided timely clamping of the descending thoracic aorta, $90 \%$ of survivors have been observed to have no neurological sequelae attributable to the procedure. However, it should be emphasized that, owing to its detrimental effects, aortic clamping should not exceed a duration of 15 minutes, since longer periods are related to a mortality rate that exceeds $80-90 \% \%^{1-3,7,8,10,11}$.

As regards electrical therapy, studies on the care of cardiopulmonary arrest in critically injured patients, both in urban and military settings, including some resuscitations following EDT protocols, have failed to find statistical difference between core rhythms reversal rates obtained either with internal or external defibrillation ${ }^{1-6,6-8,11,12}$; therefore, up to this moment, and with the available elements, it is not possible to determine if internal defibrillation is less beneficial than its external therapeutic counterpart.

In summary, EDT is a procedure that was born from the need to provide care for critically injured, agonizing patients. Within its institutional protocol, EDT includes essential aspects concerning cardiac massage, electric therapy and blood flow redistribution maneuvers (clamping of the descending thoracic aorta), which are fully applicable to the patient with non-traumatic PEA and that can significantly modify the natural course of the pathophysiology of cardiovascular collapse, thus promoting a benefit in the prognostic indexes related to survival and functionality ${ }^{1-12}$. However, global experience with this encouraging procedure is scarce and its true utility can only be proven with the passage of time and by acquiring experience with its use.

\section{Conclusions}

Although EDT is mainly instituted in injured, agonizing victims, its use in non-traumatic PEA is emerging as a possibly useful therapeutic alternative, which may result in its inclusion in advanced cardiovascular 
care protocols. However, validation of this observation should await the results that over a large number of cases only a multicenter study with an appropriate methodological design can provide to the scientific community.

\section{Acknowledgements}

The authors thank the medical and nursing staff from the Intensive Medicine and Emergency Departments, as well as the Head of the Area of Surgery at Hospital Central Militar, for providing the assistance and logistic support required for the recovery of the patient. Similarly, we would like to acknowledge the role that as collaborators in their specialty areas the following health professionals played in the preparation of this manuscript: Critically ill Patient Care Medicine, Deniria Alejandra Rugerio Trujillo, MD, and Major Miriam Seleste Ramírez Valdés, MD; Medical-Surgical Emergency Medicine, Major Juan Antonio Ramos Martinez, MD; Trauma Surgery, Major Óscar Enrique Pérez Morales, MD.

\section{References}

1. García-Núñez LM, Núñez-Cantú $O$, Hernández-García EF, Petrone $P$, Asensio JA. Toracotomía en el departamento de urgencias: unificar conceptos para protocolizar su práctica. Rev Sanid Milit Méx. 2011;65:23-31.

2. García-Núñez LM. Toracotomía en el departamento de urgencias: errores graves... pero comunes. Ciruj Gen. 2011;33(Supl 1):S65-7.

3. García-Núñez LM, Hernández-García EF. Toracotomía en el departamento de urgencias: estado del arte para el cirujano general. PROACI. 2016;1(1):9-34. (Consultado el 3/11/2017.) Disponible en: http://secad. com.mx/wp-content/uploads/2016/08/PROACI-Articulo-muestra-Toracotomia-en-el-Departamento-de-Urgencias.pdf.

4. Kornhall DK, Dolven T. Resuscitative thoracotomies and open chest cardiac compressions in non-traumatic cardiac arrest. World J Emerg Surg. 2014;9:1-6.

5. Eldor J, Frankel DZN, Davidson JT. Open chest cardiac massage: a review. Resuscitation. 1988:16:155-62.

6. Alifimoff JK. Open versus closed chest cardiac massage in non-traumatic cardiac arrest. Resuscitation. 1987;15:13-21.

7. García-Núñez LM. Toracotomía en el departamento de urgencias. En: García-Núñez LM, editor. Cirugía avanzada en trauma (C.A.T.). Principios teóricos y de aplicación práctica. Ciudad de México: Graphimedic; 2016. p. 80-6.

8. Cothren CC, Moore EE. Emergency department thoracotomy for the critically injured patient: objectives, indications, and outcomes. World $\mathrm{J}$ Emerg Surg. 2006;1:1-13.

9. García-Núñez LM, Tëras J, Cabello-Pasini R, Loera-Torres MA. Cesárea perimortem. La visión del cirujano de trauma sustentada en una revisión multiinstitucional de la literatura. Rev Sanid Milit Méx. 2006:60:217-29.

10. Robertson $C$. Open-chest cardiac massage for non-traumatic cardiac arrest. Arch Emerg Med. 1987;4:207-10.

11. Robertson $C$. The value of open chest $C P R$ for non-traumatic cardiac arrest. Resuscitation. 1991;22:203-8.

12. Banghu A, Nepogodiev D, Bowley DM. Outcomes following military traumatic cardiorespiratory arrest: the role of surgery in resuscitation. Resuscitation. 2013:84:23-4. 